\title{
THE EFFECT OF MOTIVATION ON EMPLOYEE PERFORMANCE IN BIOLOGICAL PRODUCT DIVISION OF PT MEDION BANDUNG BARAT
}

\author{
Arif Yusuf Hamali $^{1}$; Ai Siti Khodijah ${ }^{2}$; Ine Febriyanti ${ }^{3}$ \\ Prodi Komputerisasi Akuntansi, Politeknik PIKSI Ganesha Bandung \\ Jln. Jend. Gatot Subroto 301, Bandung, Jawa Barat, Indonesia 40274 \\ 'arifyusufhamali@yahoo.co.id; ${ }^{2}$ ayaythea@gmail.com; ${ }^{3}$ neozrcq@gmail.com
}

\begin{abstract}
This research was conducted at Biological Product Division of PT Medion Bandung Barat, aimed to determine correlation of motivation and employee performance, and also to analyze the effect of motivation on employee performance at Biological Product Division of PT Medion Bandung Barat. Respondents of this research were 45 people, selected with simple random sampling technique. The methods used were descriptive and associative, which tested the connection using the Spearman rank correlation analysis, and to determine the accuracy of measurement using the validity and reliability test. Results of the validity and reliability test of variables $X$ and $Y$ are valid and reliable. Calculations were performed using SPSS software version 19. The result of this study showed that motivation is in the category of good and employee performance is also in the category of good. Results showed the correlation of motivation with employee performance at Biological Product Division of PT Medion Bandung Barat with correlation coefficient of 0,568. Based on the criteria champion, this relationship is in the criteria of strong enough relationship. Results of this calculation showed the coefficient of determination is 32,26\%. It is showed that the hypothesis is proved that there is an influence of motivation to employee performance at Biological Product Division of PT Medion Bandung Barat.
\end{abstract}

Keywords: correlation; motivation; employee performance

\begin{abstract}
ABSTRAK
Penelitian ini dilaksanakan pada Divisi Produk Biologis dari PT Medion Bandung Barat yang bertujuan untuk menentukan korelasi antara motivasi dan performa dari karyawan, dan juga untuk menganalisa efek motivasi terhadap performa karyawan pada Divisi Produk Biologis dari PT Medion Bandung Barat. Responden pada penelitian ini berjumlah 45 orang, dipilih dengan teknik simple random sampling. Metode yang digunakan adalah metode deskriptif dan asosiatif, yang hubungannya diuji menggunakan analisis korelasi Spearman rank, dan untuk menentukan akurasi dari pengukuran menggunakan validity dan reliability test. Hasil dari validity dan reliability test untuk variabel $X$ dan $Y$ adalah valid dan reliabel. Penghitungan menggunakan software SPSS versi 19. Hasil dari penelitian ini menunjukkan bahwa motivasi termasuk dalam kategori baik dan performa karyawan juga termasuk dalam kategori baik. Hasil menunjukkan adanya korelasi dari motivasi dengan performa karyawan dari Divisi Produk Biologis pada PT Medion Bandung Barat dengan koefisien korelasi adalah 0,568. Dari kriteria tersebut, hubungan ini menunjukan bahwa kriteria cukup kuat. Hasil dari penghitungan menunjukan koefisien determinasi adalah 32, 36\%. Dapat dilihat bahwa hipotesis tersebut terbukti, bahwa adanya pengaruh motivasi terhadap performa karyawan pada Divisi Produk Biologis dari PT Medion Bandung Barat.
\end{abstract}

Kata kunci: korelasi; motivasi; performa karyawan 


\section{INTRODUCTION}

Motivation to perform an activity appears because there are needs to be fulfilled. If needs are fulfilled, the motivation will weaken, then an idea is developed that motivation is also to achieve particular goals (Wibowo, 2013). Motivation can be developed if there are new needs and goals. If fuilfilling needs is human interest, the goals can be human or organizational interest. Employees who have motivation to achieve their private goal must increase their performance. If employee performance is increased, the organizational performance will be increased too, which will affect individual, group and organizational performance to develop. One way to motivate an employee starts from learning how to affect individual behavior.

Motivation affects employee performance positively and significantly (Santoso, 2005; Glorianto, 2005; Sulastri, 2007; Teguh, 2009; Helmy, 2010; Wiratmoko, 2011; Harshanty, 2011; Amianti and Supriyanto, 2012; Soekardi, 2012; Bachtiar, 2012; Ekaningsih, 2012; Haryono, 2012; Mishan, 2012; Andayani, 2012; Iskandar, 2012; Murti and Srimulyani, 2013; Negara, dkk, 2014). Intrinsic motivation such as job responsibility, opportunity for improvement, and job satisfaction affects employee performance significantly, but intrinsic motivation like other's achievement and recognition does not. (Juliani, 2007).

Working motivation has positive relationship with employee performance as shown in employee behavior through self development like trainings, responsibility on tasks given by superior, appreciation and promotion based on performance evaluation (Sjafei, 2011). The fluctuation of employee performance can be seen from the motivation given to employee. Someone who has high motivation in work tends to do the job well and maximally (Murty and Hudiwinarsih, 2012).

PT Medion is a company moving in vitamin, vaccine, and weft production for fowl, which is located in Batujajar Permai Cimareme industry district - Bandung Barat. The declining of work motivation in Biological Product division of PT Medion Bandung Barat is shown in Table 1.

Table 130 Employees' Opinion about the Cause of Work Motivation Declining Based on Initial Interview in Biological Product Division of PT Medion Bandung Barat

\begin{tabular}{ccc}
\hline Employees' Opinion & YES & NO \\
\hline Health insurance given by company is adequate & -- & 30 \\
Employees are involved in management decision making & -- & 30 \\
\hline
\end{tabular}

Source: the result of initial interview in Biological Product division of PT Medion Bandung Barat, 2015

Data in the table above shows that health insurances given by company are inadequate, since they are only provided to the employees and are not applicable for their families. Also, the employees state that they have not been involved in management decision making, so when there is problem, there is no solution based on objective considerations from the employees. The phenomena of employee performance in Biological Product division of PT Medion Bandung Barat based on data obtained from HRD shows that it is not optimal. The non-optimal employee performance is based on assessment data of achievement obtained from HRD, which is: (1) employees are not skilled and swift in working; (2) employees do not understand the work instructions given by superior well; and (3) employees also do not have good knowledge about the tasks that must be done.

The other phenomena, which causes the non-optimal employee performance is inadequate facility and unconducive organizational climate. Those phenomena are shown in Table 2. 
Table 230 Employees' Opinion about the Cause of Non-Optimal Employee Performance Based on Initial Interview in Biological Product Division of PT Medion Bandung Barat

\begin{tabular}{lcc}
\hline \multicolumn{1}{c}{ Employees' Opinion } & YES & NO \\
\hline Facility like office inventory given by company is complete & -- & 30 \\
Employees' workplace is adequate (supported by the room size, lighting, ventilation, & -- & 30 \\
air conditioner) & -- & 30 \\
Organizational climate like work atmosphere is conducive & \\
\hline Source: the result of initial interview in Biological Product division of PT Medion Bandung Barat, 2015
\end{tabular}

Source: the result of initial interview in Biological Product division of PT Medion Bandung Barat, 2015

Based on the explanation and data in Table 2, the analyzed problem can be formulated. First, it is how motivation and employee performance in Biological Product division of PT Medion Bandung Barat are. Second, whether there is significant effect of motivation on employee performance in Biological Product division of PT Medion Bandung Barat. The goal of this research is to find out the relationship between motivation and employee performance in Biological Product division of PT Medion Bandung Barat. This research is also to find out that there is significant effect of motivation on employee performance in Biological Product division of PT Medion Bandung Barat.

The term of motivation is from Latin, movere, which means "move" (Winardi, 2002). Motivation is formulated as psychological process, causing persistence of voluntary activities to appear, direct, and happen for particular goal. A very motivated person is someone who does substantial effort to support the production goal and organization where that person works. A person who is not motivated only provides minimum effort in working. Motivation is not the only important determinant for individual performance, since there are other determinants such as deployed working effort, ability of connected person, and previous work experiences.

Motivation to perform an activity appears because there are needs to be fulfilled. The motivation will weaken if the needs are fulfilled. Motivation is a push on series process of human behavior to achieve goal (Wibowo, 2013). The contained element in motivation covers element of raising, directing, protecting, showing intensity, continuity, and goal. There is common interest between humans as workers and organization. On one side, workers work for compensation to fulfill their needs, and on the other side, for achieving goal to actualize their work achievement. Organizational performance is actualized by the collection of performance from all workers to achieve organizational goal.

The understanding of motivation term is classified into motive, motivation and work motivation (Mangkunegara, 2007). Motive is stimulated need orienting in individual goal in achieving satisfaction. Motivation is defined as a condition which moves human to particular goal. Work motivation means a condition which has influence in rising, directing and maintaining behavior related to work environment.

The dimensions of motivation based on hierarchy of needs by Maslow (in Mangkunegara, 2007) consist of: (1) physiological need is needs to eat, drink, have physical protection, breath and sex. (2) Safety needs is needs for protection from threat, danger, argument, and environment. (3) Social needs or sense of belonging needs, which is needs to be accepted by group, affiliated, interacted, and needs to love and to be loved. (4) Esteem needs is needs to be respected and appreciated by others, and (5) self actualization need is needs to use ability, skill and potency.

The dimensions of motivation analyzed in Biological Product division of PT Medion Bandung Barat are: (1) safety need consists of indicators like health insurance and pension insurance, (2) Social need consists of indicators such as employees' involvement in decision making and relationship 
between colleagues, (3) Esteem need consists of appreciation indicators on employees' achievement and fair treatment from superior.

Performance is defined as the result of work or work achievement (Wibowo, 2013). Actually, performance has wider definition; it is not only about work achievement, but also how the process of working takes place. Performance is the result of work which has a strong relationship with strategic goal of organization, consumer satisfaction, and contribution to economy. Performance is about what is done and how to do it.

The concept of performance is abbreviation of work and kinetic energy which in English is Performance (Wirawan, 2009). The performance term is often said as performa or kinerja in Bahasa Indonesia. Performance is the output resulted from functions or indicators of a job or profession in particular time. Job is activity of completing or making a thing which only needs power and particular skill done by blue collar worker. Profession is job which needs mastering and applying knowledge that has been studied in university like done by professional or white collar worker.

The performance term is from job performance and actual performance. The meaning of job performance is the result in quality and quantity achieved by an employee in performing the task with responsibility given (Mangkunegara, 2007). The dimensions or factors that affecting performance are: (1) ability factor, which is psychological factor owned by an employee in form of potential ability (IQ) and ability (knowledge + skill); and (2) mental factor, which is factor formed from employee's behavior in facing work situation psychophysically. An employee must be ready mentally and physically, understands the main goal and target which will be achieved, utilized and created in working situation.

The dimensions of performance analyzed in Biological Product division of PT Medion Bandung Barat are: (a) ability factor consists of indicators like accuracy in completing work, precision and seriousness in working, ability and quickness in working, understanding of work instruction, and knowledge of task. (b) Mental factor consists of indicators like direction and trust from superior, colleagues' support, adequate facility, and conducive work climate. Based on the explanations, the hypothesis then can be formulated that it is expected for motivation to affect employee performance significantly in Biological Product division of PT Medion Bandung Barat. The framework of Research can be seen in Figure 1.

Independent Variabel (X)

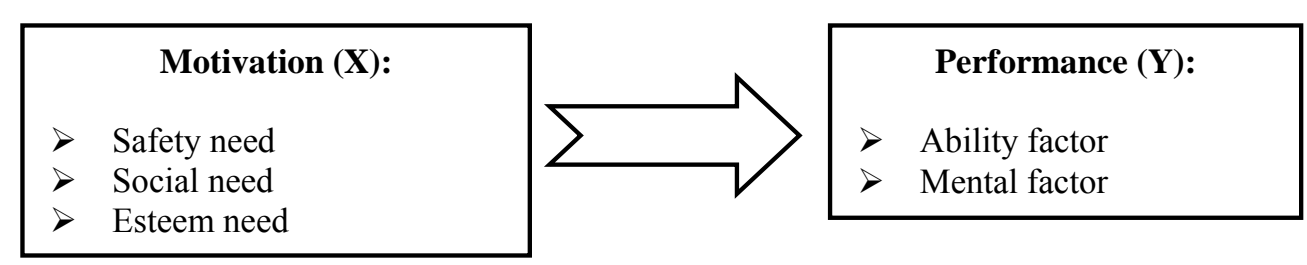

Figure 1 Framework

\section{Dependent Variabel (Y)}

\section{METHOD}

Research methods used in this research are descriptive and associative. Basically, descriptive research is a process of generalization of a research result based on one sample and its research variable is independent, so the hypothesis is not in form of comparison or the relation between two variables or more (Sugiyono, 2006). Associative research aims to analyze the relation between 
variables in population through the variable relation data in sample, while the hypothesis is to test the existing correlation coefficient on the sample that is to be applied to all samples taken (Sugiyono, 2006).

Population is generalization of territory consisting of object/subject that have particular quality and characteristic as set by researcher to be studied, and then will be concluded (Sugiyono, 2006). Population of this research is employees in Biological Product division of PT Medion Bandung Barat, approximately 51 people. The sample is the amount and characteristic which is owned by the population (Sugiyono, 2006). The determination of sample in this research uses Slovin's formula:

$$
\mathrm{n}=\frac{\mathrm{N}}{1+\mathrm{N}(\mathrm{e}) 2}
$$

Description:

$\mathrm{n}=$ Sample

$\mathrm{N}=$ Population

$\mathrm{e}=$ the percent of inaccuracy due to mistake in taking sample that can still be tolerated, taken $=5 \%$

$$
\begin{gathered}
\mathrm{n}=\frac{51}{1+51(0.05) 2} \\
n=\frac{51}{1+0,1275}=45,23 \text { rounded to } 45 \text { people }
\end{gathered}
$$

With $\mathrm{N}=51$ and $\mathrm{e}=5 \%$, it is obtained that $\mathrm{n}=45,23$ rounded to 45 . Thus, the sample is about 45 respondents. The technique of sampling done is simple random sampling because the sampling is performed randomly without paying attention to the level in the population, and this is done if the population is considered as homogeny (Sugiyono, 2006). Data used in this research is primary source data and secondary data. Primary data is a collection of data done directly on the analyzed object to obtain the answer from the respondents. Secondary data is data obtained from company, literature, and other information which are considered relevant and supporting the research. Method used to collect data is closed system questionnaire, which means for each question it is provided with the answers. Questionnaire used in this research is Likert scale. The scale is made by gradation from strongly disagree ( score $=1$ ) to strongly agree $($ score $=5$ ).

Analysis obtained in this research is descriptive and associative. Descriptive analysis uses weighting analysis, and to find the standard weight value, it can be completed by finding the length of weight range. The standard weight value can be determined by finding the length of weight range from five classifications, with step as follows:

$$
\mathrm{R}=\frac{\text { (the highest score } \mathrm{x} \text { the amount of sample) }- \text { (the lowest score } \mathrm{x} \text { amount of sample) }}{5}
$$

Description:

$\mathrm{R}=$ the range of classification

$$
\mathrm{R}=\frac{(5 \times 45)-(1 \times 45)}{5} \mathrm{R}=36
$$


The weighting is divided into five levels based on the classification above, started from the lowest level to the highest level with the weight range above 36 . The classification of standard weight value is generated in Table 3 .

Table 3 The Standard Weight Value

\begin{tabular}{cc}
\hline Weight value & Category \\
\hline $45-80$ & Worst \\
$81-116$ & Worse \\
$117-152$ & Enough \\
$153-188$ & Good \\
$189-224$ & Best \\
\hline (Source: the result of processing primary data, 2015)
\end{tabular}

(Source: the result of processing primary data, 2015)

Associative analysis is done to see how the effect of independent variable on dependent variable, in this case, the effect of motivation (X) on employee performance (Y) in Biological Product division of PT Medion Bandung Barat, by using Spearman's rank:

$$
r_{1}=1-\left[\frac{6 \sum d_{i^{2}}}{N^{3}-N}\right]
$$

Where:

$\mathrm{r}_{1}=$ correlation analysis

$\mathrm{d}_{\mathrm{i}}=$ difference of two variable

$\mathrm{N}=$ sample

The test of correlation coefficient is done to find out the truth of hypothesis presented in this research by using t-test formula:

$$
t=\sqrt[r]{\frac{N-2}{1-r^{2}}}
$$

Where:

$\mathrm{r}=$ correlation coefficient

$\mathrm{N}=$ sample

T-test is performed to prove that motivation variable (independent variable) affects employee performance ( $Y$ variable) significantly, with provision as follows: (1) if $t_{\text {count }}>t_{\text {table }}$, then motivation affects employee performance significantly, or Ho is rejected and $H_{1}$ is accepted. (2) If $t_{\text {count }}<t_{\text {table, }}$ motivation does not affect employee performance significantly, or $\mathrm{Ho}$ is accepted and $\mathrm{H}_{1}$ is rejected.

The calculation in data analysis of this research uses SPSS Software version 19. The next step is analyzing the correlation to see the effect of motivation on employee performance by using Coefficient of Determination with this formula:

$$
K D=r^{2} \times 100 \%
$$


Correlation or cohesion of the relation between free variable and bound variable is classified by Kuncoro and Riduwan (2007), as seen in Table 4.

Table 4 Interpreting Correlation Coefficient of R Value

\begin{tabular}{cc}
\hline Coefficient interval & Level of relation \\
\hline $0,80-1,000$ & Very strong \\
$0,60-0,799$ & Strong \\
$0,40-0,599$ & Strong enough \\
$0,20-0,399$ & Weak \\
$0,00-0,199$ & Very weak \\
\hline (Source: Riduwan and Kuncoro (2007))
\end{tabular}

\section{RESULTS AND DISCUSSION}

The result of validity test on $\mathrm{X}$ variable (motivation) and $\mathrm{Y}$ variable (employee performance) states all is valid, based on the criteria if correlation coefficient or $r$ count $>0,3$ with significance degree $5 \%(\alpha=5 \%)$, then the statement is valid. The result of validity test on motivation variable and employee performance variable are shown in Table 5 and 6.

Table 5 Validity Test for Motivation Variable (X)

\begin{tabular}{lcc}
\hline \multicolumn{1}{c}{ Question } & r count & description \\
\hline Health insurance & 0,681 & Valid \\
Pension insurance & 0,734 & Valid \\
Involvement in decision making & 0.848 & Valid \\
Work relationship between colleagues & 0,721 & Valid \\
Appreciation on employee's achievement & 0,831 & Valid \\
Fair treatment from superior & 0,896 & Valid \\
\hline
\end{tabular}

(Source: the result of processing primary data, 2015)

Table 6 Validity Test for Employee Performance Variable (Y)

\begin{tabular}{lcc}
\hline \multicolumn{1}{c}{ Question } & r count & description \\
\hline Accuracy in completing work & 0,786 & Valid \\
Seriousness and precision in working & 0,938 & Valid \\
Ability and quickness in working & 0,721 & Valid \\
Understanding of work instruction & 0,844 & Valid \\
Good knowledge of task & 0,859 & Valid \\
Direction and trust from superior & 0,645 & Valid \\
Colleagues' support & 0,637 & Valid \\
Communication between superior and subordinate & 0,915 & Valid \\
Adequate facility & 0,713 & Valid \\
Conducive work climate & 0,848 & Valid \\
\hline
\end{tabular}

(Source: the result of processing primary data, 2015) 


\section{Reliability Test on Research Instrument}

The result of reliability test on $\mathrm{X}$ instrument variable (motivation) and $\mathrm{Y}$ variable (employee performance) states that all is reliable. The result of reliability test on motivation variable and employee performance variable is shown in Table 7 and Table 8.

Table 7 The Result of Reliability Test on Motivation Variable

Reliability Statistics

\begin{tabular}{cc}
\hline Cronbach's Alpha & N of Items \\
.877 & 6 \\
\hline
\end{tabular}

Table 8 The Result of Reliability Test on Employee Performance Variable

Reliability Statistics

\begin{tabular}{cc}
\hline Cronbach's Alpha & N of Items \\
.932 & 10 \\
\hline
\end{tabular}

The result of descriptive average weighting for motivation variable shows average value of weight about 177 in good category. This result can be concluded that overall employees' motivation in Biological Product division of PT Medion Bandung Barat is good. However, the dimension of safety need has weight value below the average of motivation variable, which is on health insurance about 175 , and dimension of social need on indicator of involvement of employees in decision making. The cause of motivation declining is that the program of health insurance applies only for the employees, not for their family. The other cause is employees have never been involved in management decision making by superior, so when there is a problem, employees feel their social need is not fulfilled since their opinion as members of organization are not accepted and appreciated. The result of average weight value on respondents' opinion about motivation in Biological Product division of PT Medion Bandung Barat is shown in Table 9.

Table 9 Respondents' Opinion about Motivation Variable

\begin{tabular}{|c|c|c|c|c|c|c|c|c|}
\hline \multirow{2}{*}{ No } & \multirow{2}{*}{ Dimension } & \multirow{2}{*}{ Indicator } & \multicolumn{5}{|c|}{ Respondents' opinion } & \multirow{2}{*}{$\begin{array}{c}\text { Weight } \\
\text { Average weight } \\
\end{array}$} \\
\hline & & & 5 & 4 & 3 & 2 & 1 & \\
\hline \multirow{2}{*}{1} & Safety need & - Health insurance & 9 & 24 & 10 & 2 & 0 & \multirow{2}{*}{178} \\
\hline & & - Pension insurance & 11 & 24 & 10 & 0 & 0 & \\
\hline \multirow{3}{*}{2} & \multirow{2}{*}{ Social Need } & - Involvement in decision making & 11 & 21 & 8 & 5 & 0 & \multirow{2}{*}{175} \\
\hline & & - Work relationship between colleagues & 11 & 20 & 13 & 1 & 0 & \\
\hline & & - Appreciation on employee's & 13 & 21 & 9 & 2 & 0 & \multirow{3}{*}{179} \\
\hline \multirow[t]{2}{*}{3} & Esteem Need & achievement & & & & & & \\
\hline & & - Fair treatment from superior & 12 & 22 & 7 & 4 & 0 & \\
\hline & Average & & & & & & & 177 \\
\hline
\end{tabular}

Source: the result of processing primary data, 2015

The result of descriptive average weighting for performance variable shows average value of weight about 165 in good category. Thus, it can be concluded that overall employee performance in Biological Product division of PT Medion Bandung Barat is good. However, there are dimensions that are below the average of performance variable, which are ability factor with indicators like skill and 
swiftness in working, understanding of work instruction, and good knowledge of task. Mental factor also has weight value below the average of performance variable, such as adequate facility and conducive work climate.

The result of average weight value on respondents' opinion about employee performance in Biological Product division of PT Medion Bandung Barat is shown in Table 10.

Table 10 Respondents' Opinion about Performance Variable

\begin{tabular}{|c|c|c|c|c|c|c|c|c|c|}
\hline \multirow{2}{*}{ No } & \multirow{2}{*}{ Dimension } & \multirow{2}{*}{ Indicator } & \multicolumn{5}{|c|}{ Respondents' opinion } & \multirow{2}{*}{ weight } & \multirow{2}{*}{$\begin{array}{c}\text { Average } \\
\text { weight }\end{array}$} \\
\hline & & & 5 & 4 & 3 & 2 & 1 & & \\
\hline \multirow{5}{*}{1} & \multirow{6}{*}{ Ability facctor } & Accuracy in completing work & 9 & 26 & 10 & 0 & 0 & 179 & \multirow{5}{*}{159} \\
\hline & & Seriousness and precision in working & 11 & 17 & 17 & 0 & 0 & 174 & \\
\hline & & Ability and quickness in working & 4 & 19 & 16 & 6 & 0 & 156 & \\
\hline & & Understanding of work instruction & 5 & 11 & 24 & 5 & 0 & 151 & \\
\hline & & Good knowledge of task & 5 & 8 & 14 & 18 & 0 & 135 & \\
\hline \multirow{5}{*}{2} & & Direction and trust from superior & 15 & 24 & 6 & 0 & 0 & 189 & \multirow{5}{*}{170} \\
\hline & \multirow{4}{*}{ Mental factor } & Colleagues' support & 15 & 23 & 7 & 0 & 0 & 188 & \\
\hline & & $\begin{array}{l}\text { Communication between superior and } \\
\text { subordinate }\end{array}$ & 11 & 17 & 15 & 2 & 0 & 172 & \\
\hline & & Adequate facility & 4 & 19 & 16 & 2 & 4 & 152 & \\
\hline & & Conducive work climate & 5 & 11 & 23 & 6 & 0 & 150 & \\
\hline
\end{tabular}

Source: the result of processing primary data, 2015

The effect of motivation on employee performance in Biological Product division of PT Medion Bandung Barat can be viewed using Spearman's rank correlation analysis. The result of correlation analysis by using SPSS Software version 19 , with $r$ value $=0,568$ is shown in Table 11 .

Table 11 Correlation Analysis (Nonparametric Correlations)

Correlations

\begin{tabular}{lllcc}
\hline & & Motivation & $\begin{array}{c}\text { Employee } \\
\text { performance }\end{array}$ \\
\hline & Motivation & Correlation & 1.000 & $.568^{* *}$ \\
& & Coefficient & & .000 \\
Spearman's rank & & Sig. (2-tailed) &. & 45 \\
& & Correlation & 45 & 1.000 \\
& Employee & Coefficient & $.568^{* *}$ &. \\
& performance & Sig. (2-tailed) & .000 & 45 \\
\hline
\end{tabular}

**. Correlation is significant at the 0.01 level (2-tailed).

Source: The result of processing primary data, 2015

The result of SPSS in Table 11 shows that the result is significant on significance level $\alpha=5 \%$ (sig. value (2-tailed $=0,000$ is smaller than $5 \%)$ ), which means there is significant effect of motivation on employee performance in Biological Product division of PT Medion Bandung Barat. The hypothesis test is accomplished to find out the truth of hypothesis presented in this research by using ttest, as follows: 


$$
t=\sqrt[r]{\frac{N-2}{1-r^{2}}}
$$

Where:

$\mathrm{r}=0,568$

$\mathrm{N}=45$

Therefore:

$$
\begin{gathered}
t=\sqrt[0,568]{\frac{45-2}{1-(0,568)^{2}}} \\
\mathrm{t}=4,526
\end{gathered}
$$

The value of $\mathrm{t}$ count is compared to $\mathrm{t}$ table, based on the table of distribution that $\mathrm{t}$ for $\mathrm{db}=45$ $2=42, \alpha=0,05$. For the test of two parties, it is obtained that $t=2,017$. The calculation shows the value of $t$ count is bigger than value of $t$ table which is 4,526>2,017, then $\mathrm{Ho}$ is rejected and $\mathrm{Ha}$ is accepted. Therefore, the hypothesis presented in this research is right, which means motivation affects employee performance significantly in Biological Product division of PT Medion Bandung Barat. Next is to find out the relation level, based on the criteria in table 11 , with $r$ value $=0,568$, then this relationship is in strong enough criteria. From this result $r=0,568$, it states the contribution of the dimension of $\mathrm{X}$ variable (motivation) on $\mathrm{Y}$ variable (performance), determined by Coefficient of Determination, as follows:

$$
\begin{gathered}
C D=r^{2} \times 100 \% \\
=(0,568)^{2} \times 100 \%=32,26 \%
\end{gathered}
$$

Based on the calculation, with $32,26 \%$, it means this research shows motivation affects employee performance in Biological Product division of PT Medion Bandung Barat about 32,26\%, while the rest about $67,74 \%$ is affected by other factors that are not analyzed in this research.

\section{CONCLUSION}

According to result and discussion, it can be concluded that there is significant correlation between motivation and employee performance in Biological Product division of PT Medion Bandung Barat with correlation coefficient $r=0,568$. Based on the Champion criteria with $r$ value $=0,568$, this relationship is categorized as strong enough. From Coefficient of Determination, $r^{2}=0,3226$ is obtained, meaning that in this research, motivation affects employee performance about $32,26 \%$, while the rest about $67,74 \%$ is affected by other factors that are not analyzed in this research. The result of hypothesis test using t-test shows value of $t$ count is larger than value of $t$ table $(4,526>2,017)$, thus Ho is rejected and Ha is accepted. Those results approve the hypothesis in this research that there is positive effect of motivation on employee performance in Biological Product division of PT Medion Bandung Barat.

Suggestions that can be given to the management of PT Medion Bandung Barat based on the result of this research are: first, management of the company should review the policy of health insurance, which is given not only to the employees but also to their family corresponding with existing labor law. Second, the superior should involve employees in each management decision 
making when there is problem, so they are motivated to work due to appreciation and acknowledgement as members of organization. Third, the management of company should prepare employees with education and training continuously and effectively to improve their ability, swiftness, understanding and knowledge in doing their task. Fourth, the superior should give complete and adequate facility to employees and create conducive work climate and situation to achieve optimal employee performance. Considering the result that shows motivation affects employee performance about $32,26 \%$ while the rest $67,74 \%$ is affected by other factors, for the future researchers, they can conduct a research by adding different free variable (X), such as leadership, compensation, and organizational culture which can affect employee performance.

\section{REFERENCES}

Andayani, D. (2012). Pengaruh Motivasi dan Lingkungan Kerja terhadap Kinerja Pegawai Negeri Sipil (Studi Kasus di Badan Pusat Statistik Kota Pangkalpinang dan Kabupaten Bangka). Tesis. Pangkalpinang: Program Pascasarjana Universitas Terbuka.

Amianti, I., Supriyanto. (2012). Pengaruh Motivasi Kerja terhadap Kinerja Karyawan Bagian Marketing Bank Syariah (Studi Kasus pada Karyawan PT BPRS Pemerintah Kota Bekasi). Maslahah, 1(1), 1-9.

Bachtiar, D. (2012). Pengaruh Motivasi dan Lingkungan Kerja terhadap Kinerja Karyawan. Management Analysis Journal. 1(1), 1-6.

Ekaningsih, A.S. (2012). Pengaruh Motivasi Kerja terhadap Kinerja dengan Persepsi Lingkungan Kerja sebagai Variabel Pemoderasi (Studi pada Satuan Polisi Pamong Praja Kota Surakarta). Jurnal Ilmu-Ilmu Sosial SOCIOSCIENTIS, 4(1), 19-30.

Helmy, I. (2010). Pengaruh Motivasi dan Budaya Organisasi terhadap Kepuasan Kerja dan Kinerja Karyawan PT BSI. Tesis. Jakarta: Program Pascasarjana Universitas Terbuka.

Harshanty, A.W. (2011). Pengaruh Motivasi terhadap Kinerja Karyawan Badan Perijinan Terpadu (BPT) Kabupaten Sragen. Tesis. Surakarta: Program Studi Magister Ekonomi dan Studi Pembangunan Fakultas Ekonomi Universitas Sebelas Maret.

Haryono, A. (2012). Pengaruh Motivasi Berprestasi dan Iklim Organisasi terhadap Kinerja Tenaga Administrasi Universitas Negeri Semarang. Educational Management, 1(1), 75-82.

Iskandar. (2012). Pengaruh Motivasi dan Lingkungan Kerja terhadap Kinerja Guru SMA Negeri seKabupaten Kendal. Educational Management. 1(2), 150-155.

Juliani. (2007). Pengaruh Motivasi Intrinsik Terhadap Kinerja Perawat Pelaksana di Instalasi Rawat Inap RSU Dr. Pirngadi Medan Tahun 2007. Tesis. Medan: Sekolah Pascasarjana Universitas Sumatera Utara.

Kuncoro, E.A. \& Riduwan. (2007). Cara Menggunakan dan Memaknai Analisis Jalur (Path Analysis). Cetakan pertama. Bandung: Alfabeta.

Mangkunegara, A.A. Anwar Prabu. (2007). Manajemen Sumber Daya Manusia Perusahaan. Cetakan ketujuh. Bandung: PT Remaja Rosdakarya Offset. 
Murty, Windy, A. \& Hudiwinarsih, G. (2012). Pengaruh Kompensasi, Motivasi, dan Komitmen Organisasional terhadap Kinerja Karyawan Bagian Akuntansi (Studi Kasus pada Perusahaan Manufaktur di Surabaya. The Indonesian Accounting Review. 2(2), 215-228.

Murti, H., Srimulyani, V.A. (2013). Pengaruh Motivasi terhadap Kinerja Pegawai dengan Variabel Pemediasi Kepuasan Kerja pada PDAM Kota Madiun. Jurnal Riset Manajemen dan Akuntansi. 1(1), 10-17.

Mishan. (2012). Pengaruh Motivasi Kerja Guru dan Budaya Organisasi terhadap Kinerja Guru SMA Negeri di Kota Sobolga. Tesis. Jakarta: Program Pascasarjana Universitas Terbuka.

Negara, E.K., Al Musadieq, M., dan Susilo, H. (2014). Pengaruh Motivasi terhadap Kinerja (Studi pada Karyawan PT. PLN Persero APJ Malang). Jurnal Administrasi Bisnis (JAB). 11(1), 1-9.

Santoso, E. (2005). Pengaruh Motivasi, Komitmen Organisasi, dan Locus of Control terhadap Kinerja Karyawan (Studi Menjelang Merger di PT Amarta Karya). Tesis. Semarang: Program Studi Magister Manajemen Program Pascasarjana Universitas Diponegoro.

Sugiyono. (2006). Statistika Untuk Penelitian. Bandung: Alfabeta.

Sulastri. (2007). Hubungan Motivasi Berprestasi dan Disiplin dengan Kinerja Dosen. Jurnal Optimal. $1(1), 13-21$.

Sjafei, L.M.F. (2011). Hubungan Kepemimpinan dan Motivasi terhadap Kinerja Pegawai pada Dinas Pendidikan Pemuda dan Olahraga Kabupaten Buton. Tesis. Jakarta: Program Pascasarjana Unversitas Terbuka.

Soekardi, N. (2012). Pengaruh Motivasi Kerja, Budaya Organisasi, dan Kesejahteraan Pegawai terhadap Kinerja Pegawai pada Inspektorat Kabupaten Kediri. Jurnal Ilmu Manajemen Revitalisasi. 1(3), 123-132.

Teguh, I.G.A.T. (2009). Pengaruh Kompensasi Lingkungan Kerja, dan Motivasi terhadap Kinerja Teknisi Pemegang Lisensi di PT GMF Aeroasia Denpasar. Tesis. Jakarta: Program Pascasarjana Universitas Terbuka.

Winardi, J. (2002). Motivasi dan Pemotivasian dalam Manajemen. Jakarta: Raja Persada Grafindo

Wirawan. (2009). Evaluasi Kinerja Sumber Daya Manusia: Teori Aplikasi dan Penelitian. Jakarta: Salemba Empat.

Wiratmoko, T. (2011). Pengaruh Kepemimpinan, Motivasi Kerja, dan Kompensasi terhadap Kinerja Karyawan RSIA Putra Dalima Griyaloka dan RS Bunda RS Bunda Dalima Nusaloka BSD Tangsel. Tesis. Jakarta: Program Pascasarjana Universitas Terbuka.

Wibowo. (2013). Manajemen Kinerja. Cetakan ketujuh. Jakarta: PT. RajaGrafindo Persada. 